\title{
How Much Should Managers Pay for Celebrity Endorsements?
}

\author{
Han-Kuang Tien ${ }^{1}$ \\ ${ }^{1}$ School of Continuing Education, Chinese Culture, University, Taipei, Taiwan \\ Correspondence: Han-Kuang Tien, School of Continuing Education, Chinese Culture, University, Taipei, Taiwan. \\ E-mail: hktein@sce.pccu.edu.tw
}

Received: December 1, 2016

Accepted: February 15, 2017 Online Published: March 2, 2017

doi:10.5539/ijms.v9n2p68

URL: http://doi.org/10.5539/ijms.v9n2p68

\begin{abstract}
Firms that choose to include celebrity endorsements in their advertisements are required to pay large sums in advance for these appearances, even though there is no guarantee of future sales of the target product. As such, managers require a method to evaluate the monetary value of including celebrity endorsements in advertising. In this study employing two experimental designs, we provide a rigorous and predictable framework to measure the potential marginal contribution of celebrity endorsements, which can serve as an objective standard for managers when calculating celebrity appearance budgets. Implications for researchers and practitioners are also discussed.
\end{abstract}

Keywords: celebrity endorser, celebrity premium, print advertising, conjoint analysis

\section{Introduction and Literature Review}

The celebrity-endorsement strategy has been widely adopted in the field of product advertising since its inception (Bailey, 2007; Biswas, Biswas, \& Das, 2006; Ding, Molchanov, \& Stork, 2010; Erdogan, 1999; McCracker, 1989; Seno \& Bryan, 2007). Many researchers have investigated the effectiveness of these types of strategies. Atkin \& Block (1983) showed that consumers can be influenced by well-known endorsers due to their attractiveness and likeable qualities. This is supported by the estimation that approximately $14 \%$ to $19 \%$ of all television commercials in the United States feature a famous person (Creswell 2008; Spry, Pappu, \& Cornwell, 2011); moreover, $40 \%$ of youth-product advertisements in China feature celebrity endorsement (Chan, 2008; Hung, Chan, \& Tse, 2011).

Existing research on celebrity endorsement has predominantly addressed four issues: why the celebrity endorsement strategy is effective, how marketers select appropriate celebrities, when negative events happen to the celebrities leading to a risk image problem of endorsing products, and how to assess the economic value of celebrity endorsement. The first issue concerns both the source credibility theory and the source attractiveness theory (Applbaum \& Anatol, 1973; Erdogan, 1999; Hovland \& Weiss, 1951; Meenaghan, 1995; Spry, Pappu, \& Cornwell, 2011). Source credibility theory suggests that the effectiveness of a celebrity endorsement originates from their trustworthiness, while the source attractiveness theory states that the effect is based on their likability, familiarity, and similarity. Moreover, source credibility and attractiveness have both been proven to have a significant effect on consumer attitudes toward endorsed products, which further influence consumer preferences and purchase intentions (Berscheid, Dion, Walster, \& Walster, 1971; Erdogan, 1999; Lavidge \& Steiner, 1961; Patzer, 1983).

The second issue pertains to selecting an "appropriate" celebrity and has been discussed mostly from the perspective of the product match-up hypothesis - images of both the celebrity and the product should be congruent in order to generate positive advertising effects (Erdogan, 1999; Hung, Chan, \& Tse, 2011; Meenaghan, 1995; Pringle \& Binet, 2005; Till \& Busler, 2000). Erdogan \& Drollinger (2008) found that most advertising agents followed the product match hypothesis, and proposed a normative model to delineate the selection process of celebrity endorsements.

The third issue is regarding to when negative events happen to celebrity endorsers. Some marketing scholars claim that utilized celebrity endorsers in advertising has a risk problem when during or after an advertising campaign negative thing about the celebrity becomes release (Louie, Kulik, \& Jacobson, 2001; Till \& Shimp, 1998; Zhou \& Whitla, 2013). The findings of the research by Till \& Shimp (1998) show that negative information about a celebrity (only for a fiction celebrity) can ruin product evaluations of endorsing brand. However, Bailey (2007) found that those negative events with sports celebrities had little impact on their 
perception of brands or companies. If we defined a celebrity as a brand, a real celebrity has been accumulated positive celebrity equity (Seno \& Lukas, 2007). When negative information involves with that celebrity, it might damage product evaluations through associative link between brand and that celebrity at that time. An interesting observation case, Ching-Ming Wang (former Yankee starter now returns for minor-league), has been involved a scandal (an affair) in 2012. At that time, those firms (such as Acer computer, E. Sun Bank) terminated endorsement contracts immediately. However, Wang has a great performance in 2013 WBC (World Baseball Classic) and media call him "The Proud of Taiwan" again. According to Kitchen (2010) definition, brand equal to identity and reputation. Thus, examines celebrity effectiveness might have a long-term and dynamic perspective.

The Four issues refer to an emerging, prominent research field. Researchers have examined the economic value of celebrity endorsements by calculating the impact on a firm's financial performance. For instance, Agrawal \& Kamakura (1995) use an event study to calculate the economic worth of announcing a celebrity contract, and their findings point out that a firm announcement concerning such a contract can increase that firm's stock price by approximately $0.44 \%$. Mathur, Mathur, \& Rangan (1997) find that when Michael Jordan returned to NBA, the market-adjusted values of his endorsement firms increased by almost $2 \%$. Farrell, Karels, Monfort, \& McClatchey (2000) explore the impact of Tiger Wood's tournament performance in 1996-1997 on Nike's firm value. Further, Ding, Molchanov, \& Stork (2010) claime that celebrity endorsements restricted to technological products led to significant positive abnormal returns. Fizel, Mcneil, \& Smaby (2008) examine 148 conventional athlete endorsements excluding mega-stars - their results showed that these endorsements had an insignificant impact on the firm's market value. They mention that one possible reason for this result may be the overuse of athlete endorsers (Fizel, Mcneil, \& Smaby, 2008, p. 252). Furthermore, recent research conducted by Elberse \& Verleun (2012) utilize the intervention model to examine the impact of celebrity endorsements on the sales of specific brands rather than on a firm level.

The majority of previous studies in this area have addressed the ex-post economic worth of a celebrity; however, they do not consider issues pertaining to setting celebrity budgets prior to commercial production. As such, one important issue for marketers remains how to determine whether the celebrity remuneration is worthwhile ex-ante. Specifically, we need to develop a model to predict the economic worth of a celebrity endorsement.

We propose that the payment for a celebrity should be based on the incremental revenue associated with consumer preferences regarding celebrity endorsements. Thus, how to measure the consumer preference for a celebrity is an important task. Once marketers can determine the consumer preference for a celebrity using objective methods, they can also calculate a reasonable payment for the celebrity's endorsement of their product.

In this study, we tried to bridge theory (source attractive theory: likability) to practice (transfer consumers' likability of celebrity to a concrete contribution of endorsement contract). The current study utilizes conjoint analysis to measure the effectiveness of celebrities on consumer attitudes toward advertising, and then provided an analytical model to demonstrate the calculation of a reasonable payment for celebrities. Moreover, we validated the prediction of sales revenues created by different celebrities with a real-world data and to determine the feasibility of the proposed model. By means of this analytical model, firms can improve the accuracy of their cost estimate data (i.e., reasonable payment for celebrities), which is useful when negotiating with celebrity agents or ad agents. In addition, marketing managers can utilize this cost information to more effectively control their advertising budget.

The remainder of this study is organized as follows. In the next section, we introduce the research design and methodology, including the types of celebrities considered, the pictorial message appeals and the verbal context appeals. Section three describes the empirical results. Finally, we offer conclusions and identify opportunities for further research.

\section{Research Design and Methodology}

The framework for measuring the effectiveness of celebrity endorsements in an advertising campaign, and the impact on market performance, are shown in Figure 1. Within this conceptual framework, by controlling pictorial imagery appeals and verbal text appeals, celebrities will affect consumer purchase intentions. After estimating the part-worth of different advertisement attributes, the predicted purchase intention can be produced and utilized to simulate the market share among given brands and celebrities. Finally, the valuation of the changes in market share created by the celebrity can be transferred into the celebrity's monetary contributionthis figure can then be used as the basis of calculation for celebrity endorsement payments.

Consumers heavily use information from print ads when purchasing durable goods (Edell \& Staelin, 1983); in addition, print advertisements are very important when targeting audiences in the motor vehicle industry (TNS 
Custom Market Research, 2005). As such, we selected automobiles to be our first experimental object. In order to better generalize our results, we chose a popular consumer good (soft drink products) to be our second experimental object.

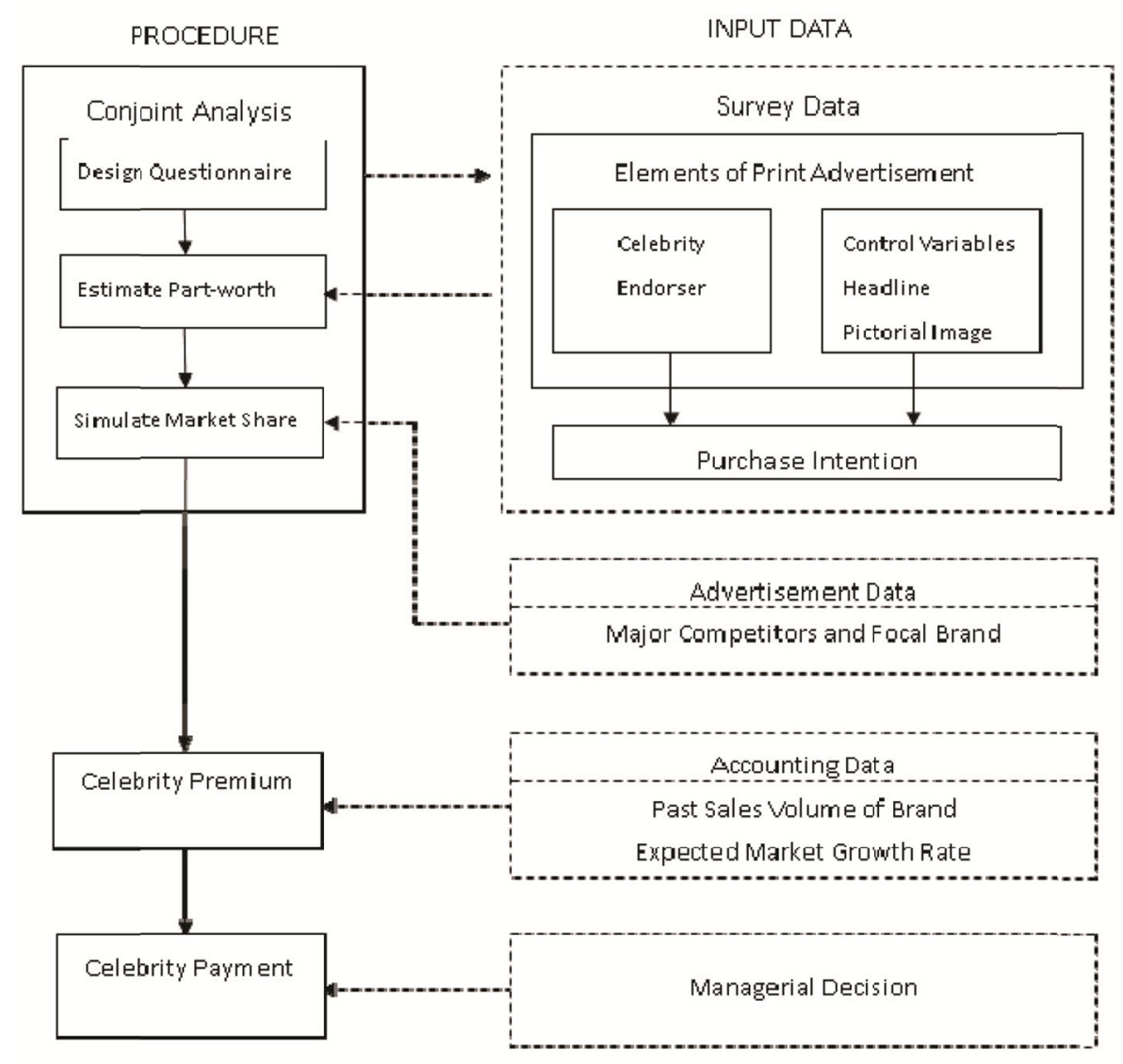

Figure 1. Research design for the calculation of celebrity endorsement payments

\subsection{Independent Variables}

In addition to the use of celebrities as a focal element in an effective print advertisement, two other components, pictures and text, are integral to this study and need to be controlled (Decrop, 2007). A dominant picture can lead to greater viewer fixation, while text can reinforce imagery processing (Babin \& Burns, 1997). Celebrities are not only seen as an important part of dominant print ad pictures, but they also represent the trustworthiness of the promotional product or service (Friedman, Santeramo, \& Traina, 1978; Poels \& Dewitte, 2008). As such, celebrity endorsers were designated as the major independent variable, together with two control variablespictorial imagery appeals and texts appeals.

\subsection{Celebrity Endorsers}

Typical types of celebrities include actors (i.e., movie stars), sports figures (i.e., professional baseball players), and entertainers (i.e., fashion models). In the current study, three famous people were selected to represent these three celebrity types: Takeshi Kaneshiro (a famous movie star in East Asia), Chien-Ming Wang (a Major League Baseball player), and Chi-Ling Lin (a super model in Greater China). These three celebrities have all recently endorsed various automobile firms: Takeshi Kaneshiro for Mitsubishi Motors, Chien-Ming Wang for Ford, and Chi-Ling Lin for Kia. According to the I-Survey Online (2007), these three celebrities share an identical awareness level among Taiwanese people; also, their annual remuneration ranged from US $\$ 350,000$ to US $\$ 470,000$.

\subsection{Pictorial Message Strategy in Print Ads}

A dominant picture can lead to viewer fixation, and often triggers audience processing of the advertising 
message (Babin \& Burns, 1997; Johar \& Sirgy, 1991). Cathelat \& Ebguy (1988) propose three types of advertising appeals that practitioners may use to attract audiences: functional appeals, social appeals, and psychological appeals. Functional appeals pertain to actual product features. As such, the product itself is the major attraction, and print ads for the product include a large depiction of the actual product. Social appeals differ in that the focal brand is treated as a part of consumers' lifestyles. This type of appeal often attempts to heighten consumers' desire for products that claim to represent ideal lifestyles. Finally, psychological appeals are based on the focal brand encouraging viewers to enter a dreamland by imagining or escaping from reality. The use of symbols and signs helps individuals to project their own self-concepts onto the focal product. All three of these pictorial imagery appeals were included in this study.

\subsection{Verbal Messages in Print Ads}

Hopkins (1996) states that "The salesperson is there to demand attention. He cannot be ignored. The advertisement however can be ignored." As such, the purpose of an advertisement headline is viewed as that of a silent salesperson - to attract the audience's attention to the focal product (Ogilvy, 1963). Verbal context plays a guiding role when framing pictures in that it helps audiences to perceive product information more completely (Edell \& Staelin, 1983). Similar to the aforementioned three types of appeals associated with the pictorial message strategy, there are also three types of verbal context appeals: functional, social, and psychological (Cathelat \& Ebguy, 1988).

Based on the structural framework for an appropriate print advertisement outlined above (see Figure 1) and the experimental conjoint design $(3 \times 3 \times 3)$, we developed a survey in order to estimate the utilities (part-worth) of the aforementioned three celebrity endorsers. Additional details on the experimental design are provided in the Methodology section, and in Appendices 1 and 3.

\subsection{Dependent Variable (Advertising Effectiveness)}

Although some marketing scholars claim that sales volume should be the primary criterion to measure advertising effectiveness (Buzzell, 1964), others have proposed that it should be measured based on how advertising influences attitudes toward the brand and consumer's purchase intention ( Wu, Lien, Fu, \& Sukoco, 2012; Yilmaz, Telci, Bodur, \& Iscioglu, 2011). As our research purpose centers on predicting the effectiveness of celebrity endorsement prior to commercial production in order to estimate the sales response associated with a given celebrity endorsement campaign, we refer to Yilmaz et al. (2011, p. 891) and define purchase intention as a dependent variable to measure the advertising effectiveness.

\subsection{Methodology}

Conjoint analysis assists researchers to obtain information regarding individual preferences for products or services (Vriens, 1994). In addition, because conjoint analysis is a trade-off model, we can estimate the part-worths of each attribute, where those part-worths are viewed as the marginal utilities. After estimating the part-worths for different advertisement attributes, the predicted purchase intention can be calculated and then utilized to simulate the market share among different combinations of appeals and celebrities.

In this study, conjoint analysis is performed using a multiple regression with dummy variables as follows:

$$
Y_{i j}=\alpha_{i}+\beta_{i 1} D_{1 j}+\beta_{i 2} D_{2 j}+\beta_{i 3} D_{3 j}+\beta_{i 4} D_{4 j}+\beta_{i 5} D_{5 j}+\beta_{i 6} D_{6 j}+\epsilon_{i j}
$$

where $Y_{\mathrm{ij}}$ is the $j^{\text {th }}$ profile of the $i^{\text {th }}$ respondent's likeability; $\alpha_{\mathrm{i}}$ is the $i^{\text {th }}$ respondent's intercept; $\beta_{i k}$ is the coefficient of the $k^{\text {th }}$ attribute-level of ads of the $i^{\text {th }}$ respondent; $D_{k j}$ is the dummy variable for the $j^{\text {th }}$ profile of the $k^{\text {th }}$ attribute-level; and $\varepsilon_{\mathrm{ij}}$ is the error term of the $j^{\text {th }}$ profile of the $i^{\text {th }}$ respondent.

All combinations of attribute-levels result in 27 (i.e., $3 \times 3 \times 3$ ) possible print ads; however, these 27 possible combinations can be reduced to nine alternatives based on an orthogonal main effect design (Addelman, 1962). All nine stimuli were designed to represent authentic full page color advertisements (see Appendices 2 and 4 for examples). We chose to employ the full profile approach because this approach allows for more realistic evaluations than pair-wise comparisons (Decrop, 2007).

In the first experiment (automobiles), we conducted a survey where 114 respondents completed the questionnaire. Respondents were predominantly male (63\%) and ranged in age from 21 to 53, with a mean age of 35.6 years. In the second experiment (soft drink products), 760 respondents completed the questionnaire. These respondents were predominantly female (66\%) and ranged in age from 16 to 50 with a mean age of 23.8 years.

\subsection{Estimating Celebrity Values}

In this section, we discuss the development of our four-step procedure to calculate the celebrity premium as well as reasonable payments for celebrity endorsers. 


\subsubsection{Step 1: Estimate Celebrity Endorsers' Part-Worth}

After conducting a conjoint analysis, we could estimate the part-worth of our chosen celebrity endorsers at the individual level. We employed 114 regression models and estimated regression coefficients for each respondent representing his/her preference structure. The $\beta_{\mathrm{i} 1}$ coefficient indicates that the $i^{\text {th }}$ respondent's preference (part-worth) for Kaneshiro was relative to that for Wang. The $\beta_{1}$ mean is -0.14 , which indicates that respondents' general preference for Wang was higher than that for Kaneshiro. Further, the $\beta_{\mathrm{i} 2}$ coefficient indicates that the $i^{\text {th }}$ respondent's preference (part-worth) for Lin was relative to that for Wang. The $\beta_{2}$ mean is -0.39 , which suggests that, on average, respondents' preference for Wang was higher than that for Lin.

\subsubsection{Step 2: Predict Purchase Share Based on Part-Worth}

Once the part-worth of different ad attributes have been estimated, the predicted purchase share can be produced and utilized to simulate the market share, based on the appeals and celebrities employed (Kamakura \& Russell, 1989; Grover \& Srinivasan, 1987). We analyzed the major print advertisement campaigns for the five automobile companies from 2002 to 2004 (i.e., Nissan X-trail, Mazda Tribute, Mitsubishi Zinger, Ford Escape, \& Honda CRV); the associated print advertisement strategies (i.e., types of pictorial images and text) were coded by two invited experts from an advertising agency. Nissan was designated as our focal firm; as such, its print ad strategy was provided by the researchers. We put the coding results into the respondents' individual regression models in order to estimate the total utilities of the five given brands in terms of individual preferences. Based on utility maximization, respondents would choose the specific brand with the highest score. The purchasing share of each brand was then calculated as the selection frequency for each brand divided by the total number of respondents.

\subsubsection{Step 3: Estimate Changes in Sales Volume}

Although the purchasing share is equivalent to the market share, they are not exactly the same. As Whitlark \& Smith (2007) claimed, conjoint analysis is based on several assumptions, including $100 \%$ product awareness and $100 \%$ saturation of the distribution channel, among others. However, the experimental products in our study (i.e., automobiles and soft drinks) are both existing products not brand new in their market; as such, these products are associated with high brand awareness and channel penetration.

Wittink \& Bergesturen (2001) suggested the use of additional information such as purchase frequency or sales volumes to modify the predicted purchasing shares. Thus, we included the previous market share in our equation, and set the current market share as the weighted average of the previous market share and the estimated purchasing share as follows:

$$
\widehat{M S}_{t}=(k) P S_{t}+(1-k) M S_{t-1}
$$

where $\widehat{M S}_{\mathrm{t}}$ is the predicted market share of the focal brand at time $t ; \mathrm{MS}_{\mathrm{t}-1}$ is the real market share of the focal brand at time $\mathrm{t}-1 ; \mathrm{PS}_{\mathrm{t}}$ is the purchasing share at time $\mathrm{t}$ obtained from Step 2; and $\mathrm{k}$ is a constant. When $\mathrm{k}$ approaches 0 , this indicates that the market share at time $\mathrm{t}-1$ is a dominant factor in terms of predicting the current market share. On the other hand, if the preference structure changes significantly, then $\mathrm{k}$ will approach 1 , which indicates that market share at time t-1 is not influential (refer to Little, 1966). The value of $\mathrm{k}$ can be determined using Brown's (1963) Exponential Smoothing equation. For example, the Automotive Research and Testing Center (2008) lists a five-year dataset for the Nissan X-trail market share (i.e., 30.88\%, 32.35\%, 30.88\%, $29.41 \%, 27.9 \%$ ), and $\mathrm{k}$ is equal to 0.652 (with $\mathrm{p}$-value $=0.04$ ).

Further, based on Brown's Exponential Smoothing equation, the predicted market share $\left(\widetilde{\mathrm{MS}}_{\mathrm{t}}\right)$ is $26.84 \%$ without considering any additional information. The difference between $\widehat{\mathrm{MS}}_{\mathrm{t}}$ and $\widetilde{\mathrm{MS}}_{\mathrm{t}}$ implies the performance of the celebrity endorsement strategy, since $\widehat{M S}_{t}$ is mainly generated by including information pertaining to consumer preferences for a specific celebrity strategy.

Subtracting $\widetilde{M S}_{t}$ from $\widehat{M S}_{t}$, we find the change in market share obtained by the use of the celebrity strategy. Then, we multiply the change in market share by the total potential market size to get the change in sales volume (CSV) as follows:

$$
C S V=\left[\widehat{M S}_{t}-\widetilde{M S}_{t}\right]\left[T S_{t-1} \times(1+\alpha)\right]
$$

where $\mathrm{CSV}$ is the change in sales volume; $\mathrm{TS}_{\mathrm{t}-1}$ is the total market sales volume over the previous year; and $\alpha$ is the expected total market growth or decline rate.

\subsubsection{Step 4: Calculate Celebrity Endorsement Premium}

Ideally, the celebrity premium should reflect the potential gross profit contribution created by his or her endorsement. As such, the celebrity premium is determined by a ratio of the change in sales volume multiplied by the gross profit. That is, 


$$
\text { Celebrity Premium }=\gamma \times(C S V) \times[P-C G S-O E]
$$

where $\mathrm{P}$ is the retail price of the product; CGS represents the cost of goods sold per product; and $\mathrm{OE}$ is the operating expense per product. The ratio can use the proportion of total advertising expenditure to annual total sales as a reference point.

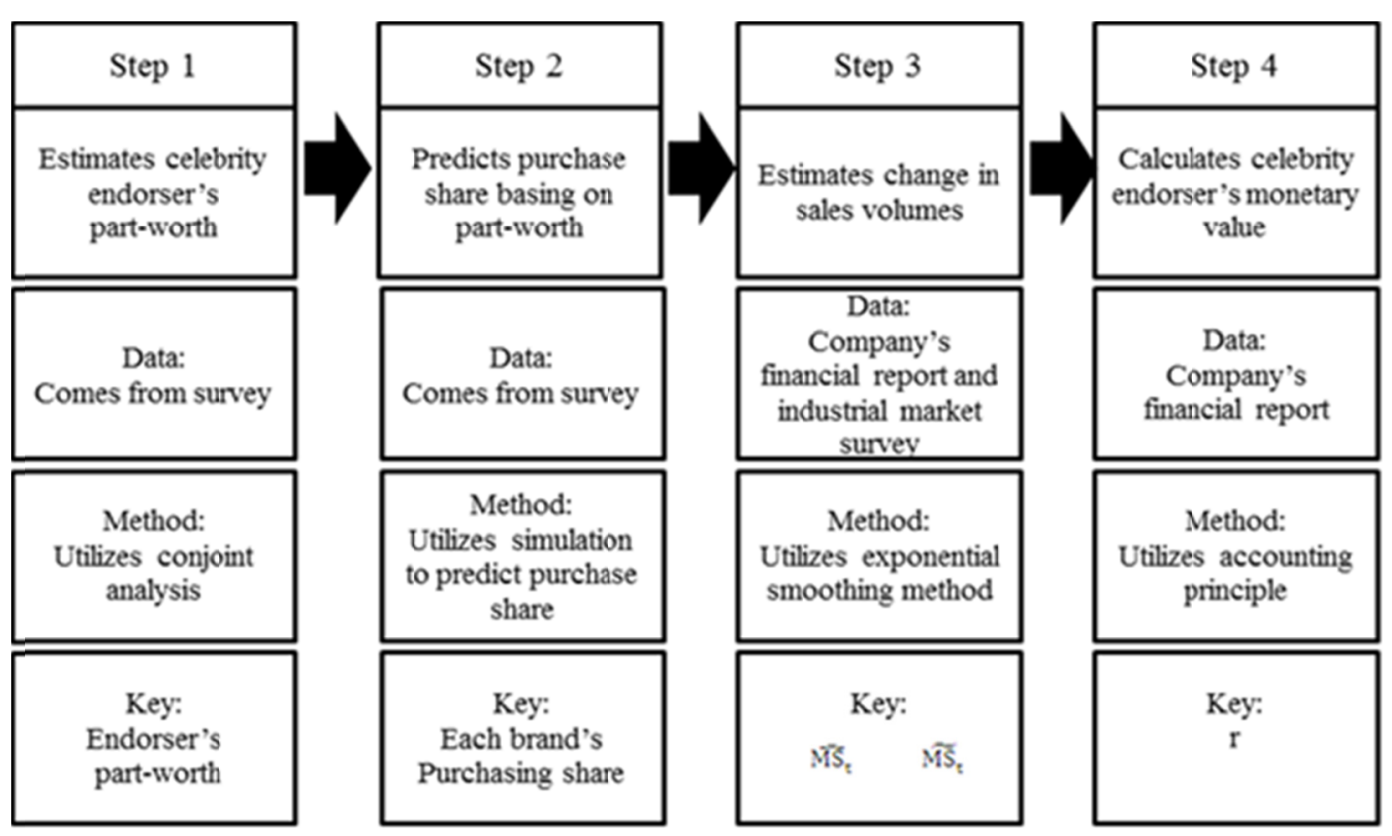

Figure 2. 4 steps for the calculation of celebrity endorsement payments

\subsection{Case Study 1: Automobile Market}

The four steps that make up the celebrity premium assessment will now be applied to the case of a vehicle product. Suppose that the marketing manager at Nissan Taiwan wanted to choose Chien-Ming Wang to promote the X-trail. First, we estimate the consumer preference for Wang through a conjoint analysis. Second, we predict the purchase share of the Nissan X-trail according to the first-choice rule, and obtain a purchase share of 0.391 . The third step involves determining the value of $k$. Employing Brown's Exponential Smoothing equation, we find that the value of $k$ is 0.652 ; via equation (2), we find that $\widehat{\mathrm{MS}}_{\mathrm{t}}$ is $33.8 \%$. Compared with the previous year (the total market sales volume was 48,471 units), the total SUV market sales volume has grown by about $19.99 \%$ (i.e., $\alpha=0.1999$ ). Also, the change in sales volume (CSV) calculated using equation (3) is equal to 4,067 units, which represents the units contributed by Chien-Ming Wang's endorsement. Finally, since the average retail price of the Nissan X-trail in Taiwan is US\$23,333, and the rratio is $8.4 \%$, the celebrity premium Nissan should offer Chien-Ming Wang is US\$1,289,868 based on equation (4). In reality the firm only paid him US\$534,000, so Taiwan Nissan gained a surplus of US\$755,868.

It may also be the case that a company overestimates the celebrity premium. Taiwan Mitsubishi Motors invited Takeshi Kaneshiro to promote the Mitsubishi Galant, a mid-compact sedan, for a total of US\$400,000. Using Brown's Exponential Smoothing equation, we obtain a $k$ value of 0.581 (p-value $=0.047$ ); via equation (2) we find that $\widehat{\mathrm{MS}}_{\mathrm{t}}$ equals $11.4 \%$. Further, considering that the average retail price of the Mitsubishi Galant in Taiwan is US\$20,000, and the $\gamma$ ratio is $2.5 \%$, equation (4) suggests that the celebrity premium for Takeshi Kaneshiro should total US\$252,429. As such, based on our model estimation, Mitsubishi Taiwan overpaid this endorser by US $\$ 147,571$.

In fact, in the end of that year, the total sales volume of the Galant was only 2,085 units, compared to the sales figure of 2,095 units from the previous year. Therefore, it appears that the endorsement of Takeshi Kaneshiro did not measurably benefit Mitsubishi Taiwan.

\subsection{Case Study 2: Soft Drinks}

To test the generalizability of the proposed model, we used soft drinks as another experiential object. 
Furthermore, we included a new level of endorser attribute (i.e., a typical consumer) and a new attribute (i.e., brand name) in our model.

Hey Song is a local but influential soft drink brand that enjoys a $32.6 \%$ market share in Taiwan; Coca Cola is the leading brand that retains about $38.2 \%$ of the market (Nielsen Taiwan, 2010). Following the aforementioned four-step procedure, based on results from equation (4), the celebrity endorsement premium brought by Takeshi Kaneshiro totals approximately US $\$ 30,353$ (i.e., nearly a quarter of the total promotion budget), due to the fact that the predicted market share increased by $3.4 \%$.

Interestingly, our results indicate that the monetary value of the same celebrity (e.g., Takeshi Kaneshiro) endorsing products in different industries (i.e., automobiles and soft drinks) differs by a large amount. This indicates that the value of the celebrity depends on target consumer preferences for different products, rather than on the celebrity's personal popularity or physical attractiveness in general.

\section{Concluding Remarks}

The seminal research of Agrawal \& Kamakura (1995) focuses on the economic value of celebrity endorsement. In addition, Elberse \& Verleun (2012) on the contribution of celebrity endorsement on a specific brand level allow marketers to calculate the performance of celebrity endorsement accurately using changes in stock price and historical sales data.

However, Montes (1992, p. 616) states that “...defining "celebrity" goodwill is like trying to nail jello to the wall." A current practical issue for marketers concerns how to determine the appropriate amount of money to pay for celebrity endorsements prior to finalizing the advertising campaign; in other words, how to measure the potential performance of the celebrity. The current study introduces a framework that integrates consumer brand preferences with financial accounting practices to calculate a reasonable and realistic celebrity monetary value. Based on the proposed framework, managers can establish an objective and standard procedure to determine how much to pay for celebrity endorsements.

In the field of professional sports, management teams consult each player's complete and official records when making contract offers (Elberse \& Verleun, 2012; Scully, 1974). Further, the entertainment industry extensively employs records or indexes (e.g., box office receipts, mass media exposure) to measure celebrity popularity. However, marketers still struggle with this type of valuation, and with the problem of converting celebrity popularity into potential endorsement contributions.

Conjoint analysis has been used widely by academics and practitioners for the last three decades (Green \& Rao, 1971; Green \& Srinivasan, 1990). In the current paper, we extend the application of conjoint analysis from traditional studies of new product development to that of celebrity performance. This methodology helps us to transform the degree of math-up celebrity with promoted product into consumer's utility and to take this utility (i.e., consumer preference) one step further to predict sales volume changes contributed by the endorsement. As such, marketing managers can use conjoint analysis to strengthen their bargaining power when negotiating with celebrity agents.

\section{Limitations and Future Research}

To the best of our knowledge, this paper is the first to scientifically and systematically calculate endorsement payments. However, our results are currently limited to print advertising endorsements. In addition, if we defined a celebrity as a brand, a real celebrity has been accumulated positive celebrity equity (Seno \& Lukas, 2007). In our study did not examine celebrity effectiveness from a long-term and dynamic perspective.

In the future, researchers may increase the sophistication and deliberation of the model by considering commercial film as the stimulus, and incorporate some additional variables (e.g., box office receipts, mass media exposure) to better predict the contribution of celebrities. Based on schema theory, scholars might check evaluations through associative link between brand and that celebrity at that time and build a systemic examination on the dynamic perspective.

\section{References}

Addelman, S. (1962). Orthogonal main-effect plans for asymmetrical factorial experiment. Technometrics, 4, 21-46. https://doi.org/10.1080/00401706.1962.10489985

Agrawal, J., \& Wagner, A. K. (1995). The economic worth of celebrity endorsers: An event study analysis. Journal of Marketing, 59, 56-62. http://dx.doi.org/10.2307/1252119

Applbaum, R., \& Anatol, K. (1973) Dimensions of source credibility: A test for reproducibility. Speech Monographs, 40, 231-237. http://dx.doi.org/10.1080/03637757309375800 
Atkin, C., \& Block, M. (1983). Effectiveness of celebrity endorsers. Journal of Advertising Research, 23, 57-61.

Automotive Research and Testing Center. (2008). Taiwan Automotive Market Sales Report.

Babin, L. A., \& Alvin, C. B. (1997). Effects of Prrint Ad Pictures and Copy Containing Instructions to Imagine on Mental Imagery That Mediates Attitudes. Journal of Advertising, XXVI(3), 33-43. http://dx.doi.org/10.1080/00913367.1997.10673527

Bailey, A. A. (2007). Public Information and Consumer Skepticism Effects on Celebrity Endorsements: Studies among Young Consumers. Journal of Marketing Communications, 13(2), 85-107. http://dx.doi.org/10.1080/13527260601058248

Berscheid, E., Karen, D., Elaine, W., \& Walster, G. W. (1991). Physical Attractiveness and Dating Choice: a Test of Matching Hypothesis. Journal of Experimental Social Psychology, 7(2), 173-189. http://dx.doi.org/10.1016/0022-1031(71)90065-5

Biswas, D., Biswas, A., \& Das, N. (2006). The Differential Effects of Celebrity and Expert Endorsements on Consumer Risk Perceptions. Journal of Advertising, 35(2), 17-31. http://dx.doi.org/10.1080/00913367.2006.10639231

Buzzell, R. D. (1964). Predicting Short-Term Changes in Market Share as a Function of Advertising Strategy. Journal of Marketing Research, 1(3), 27-31. http://dx.doi.org/10.2307/3150052

Cathelat, B., \& Ebguy, R. (1988). Styles de pub-60 manières de communiqué. Paris, Les Editions d'Organisation.

Chan, K. (2008). Using of Celebrity in Television Commercials of Young Products. Working paper, Hong Kong Baptist.

Creswell, J. (2008). Nothing Sells Like Celebrity. The New Times, June 22.

Decrop, A. (2007). The influence of message format on the effectiveness of print advertisements for tourism destinations. International of Journal of Advertising, 26(4), 505-525.

Ding, H., Molchanov, A. E., \& Stork, P. A. (2010). The Value of Celebrity Endorsements: A Stock Market Perspective. Marketing Letters (pp. 1-17). Published online: 08 June. http://dx.doi.org/10.1007/s11002-010-9117-y

Edell, J. A., \& Staelin, R. (1983). The Information Processing of Pictures in Print Advertising. Journal of Consumer Research, 10(1), 45-61. https://dx.doi.org/10.1086/208944

Elberse, A., \& Verleun, J. (2012). The Economic Value of Celebrity Endorsements. Journal of Advertising Research, 56(2), 149-165. https://dx.doi/10.2501/JAR-52-2-149-165

Erdogan, B. Z. (1999). Celebrity Endorsement: A Literature Review. Journal of Marketing Management, 15, 291-314. http://dx.doi.org/10.1362/026725799784870379

Erdogan, B. Z., \& Tanya, D. (2008). Endorsement Practice: How Agencies Select Spokespeople. Journal of Advertising Research, December, 573-582. http://dx.doi/10.2501/S0021849908080549

Farrell, K., Karels, G. V., Monfort, K. W., \& McClatchey, C. A. (2000). Celebrity Performance and Endorsement Value: The Case of Tiger Woods. Managerial Finance, 26(7), 1-15. http://dx.doi.org/10.1108/03074350010766756

Fizel, J., McNeil, C. R., \& Smaby, T. (2008). Athlete Endorsement Contracts: The Impact of Conventional Stars. International Advances in Economic Research, 14, 247-256. http://dx.doi.org/10.1007/s11294-008-9144-0

Friedman, H. H., Santeramo, M. J., \& Traina, A. (1978). Correlates of Trustworthiness for Celebrities. Journal of the Academy of Marketing Science, 6(4), 291-299. http://dx.doi.org/10.1007/BF02732313

Green, P. E., \& Rao, V. R. (1971). Conjoint Measurement for Quantifying Judgmental Data. Journal of Marketing Research, 8, 355-363. http://dx.doi.org/ 10.2307/3149575

Green, P. E., \& Srinivasan, V. (1990). Conjoint Analysis in Marketing: New Developments with Implications for Research and Practice. Journal of Marketing, 54(4), 3-19. http://dx.doi.org/10.2307/1251756

Grover, R., \& Srinivasan, V. (1987). A Simultaneous Approach to Market Segmentation and Market Structuring. Journal of Marketing Research, 24, 139-153. http://dx.doi.org/10.2307/3151504

Hopkins, C. C. (1996). My Life in Advertising \& Scientific Advertising. Lincolnwood, Illinois: NTC Business Books. 
Hovland, C. I., \& Weiss, W. (1951). The Influence of Source Credibility on Communication Effectiveness. Public Opinion Quarterly, 15, 635-650. https://doi.org/10.1086/266350

Hung, K., Chan, K. W., \& Tse, C. H. (2011). Assessing Celebrity Endorsement Effects in China: A Consumer-Celebrity Relational Approach. Journal of Advertising, 51(4), 608-623. http://dx.doi.org/10.2501/JAR-51-4-608-623

I-Survey Online. (2007). Taiwan Eastern Integrated Consumer Profile Database. Taipei. Published.

Johar, J. S., \& Sirgy, M. J. (1991). Value-Expressive Versus Utilitarian Advertising Appeals: When And Why To Use Which Appeal. Journal of Advertising, 20(3), 23-33. https://doi.org/10.1080/00913367.1991.10673345

Kamakura, W. A., \& Russell, G. J. (1989). A Probabilistic Choice Model for Market Segmentation and Elasticity Structure. Journal of Marketing Research, 26, 379-390. https://doi.org/10.2307/3172759

Kitchen, P. (2010). Integrated Brand Marketing and Measuring Returns. London, UK: Palgrave Macmillan. https://doi.org/10.1057/9780230297340

Lavidge, R. J., \& Steiner, G. A. (1961). A Model for Predictive Measurements of Advertising Effectiveness. Journal of Marketing, 25(October), 59-62. https://doi.org/10.2307/1248516

Little, J. D. C. (1966). A Model of Adaptive Control of Promotional Spending. Operations Research, 14(6), 1075-1097. http://dx.doi.org/10.1287/opre.14.6.1075

Louie, T., Kulik, R., \& Jacobson, R. (2001). When Bad Things Happen to the Endorsers of Good Products. Marketing Letters, 12(1), 13-23. http://dx.doi.org/10.1023/A:1008159717925

Mathur, L. K., Mathur, I., \& Rangan, N. (1997). The Wealth Effects Associated with a Celebrity Endorser: The Michael Jordan Phenomenon. Journal of Advertising Research, 37(3), 67-73.

McCracken, G. (1989). Who is the Celebrity Endorser? Cultural Foundations of the Endorsement Process. Journal of Consumer Research, 16(3), 310-321. https://doi.org/10.1086/209217

Meenaghan, T. (1995). The Role of Advertising in Brand Image Development. The Journal of Product and Brand Management, 4(4), 23-34. http://dx.doi.org/10.1108/10610429510097672

Montes, J. (1992). Celebrity Goodwill: Nailing Jello to the Wall. Loyola of Los Angeles Entertainment Law Review, 615-638.

Nielsen Taiwan. (2010). Retail Measurement Services: Soft Drinks Survey, Taipei. Unpublished.

Ogilvy, D. (1963). Confessions of an Advertising Man. Canada: Collier Macmillan Canada, Inc.

Patzer, G. L. (1983). Source credibility as a function of communicator physical attractiveness. Journal of Business Research, 11(2), 229-241. http://dx.doi.org/10.1016/0148-2963(83)90030-9

Poels, K., \& Dewitte, S. (2008). Getting a Line on Print Ads: Pleasure and Arousal Reactions Reveal an Implicit $\begin{array}{lllll}\text { Advertising Mechanism. Journal of } & \text { Advertising, }\end{array}$ http://dx.doi.org/10.2753/JOA0091-3367370405

Pringle, H., \& Binet, L. (2005). How marketers can use celebrities to sell more effectively. Journal of Consumer Behaviour, 4, 201-214. https://doi.org/10.1002/cb.2

Scully, G. W. (1974). Pay and Performance in Major League Baseball. The American Economic Review, 64(6), 915-930.

Seno, D., \& Bryan, L. (2007). The Equity Effect of Product Endorsement by Celebrities: A Conceptual Framework from a Co-branding Perspective. European Journal of Marketing, 41(1/2), 121-134. http://dx.doi.org/10.1108/03090560710718148

Spry, A., Pappu, R., \& Cornwell, T. B. (2011). Celebrity Endorsement, Brand Credibility and Brand Equity. European Journal of Marketing, 45(6), 882-909. http://dx.doi.org/10.1108/03090561111119958

Till, B. D., \& Busler, M. (2000). The Match-up Hypothesis: Physical Attractiveness, Expertise, and the Role of Fit on Brand Attitude, Purchase Intent and Brand Beliefs. Journal of Advertising, 29(3), 1-13. http://dx.doi.org/10.1080/00913367.2000.10673613

Till, B. D., \& Terence, A. S. (1998). Endorsers in advertising: The case of negative celebrity information. Journal of Advertising, XXVII(1), 67-82. http://dx.doi.org/10.1080/00913367.1998.10673543

TNS Custom Market Research. (2005). New Car Owners Survey, Taipei. Unpublished. 
Vriens, M. (1994). Solving Marketing Problems with Conjoint Analysis. Journal of Marketing Management, 10, 37-55. http://dx.doi.org/10.1080/0267257X.1994.9964259

Whitlark, D. B., \& Smith S. M. (2007). Sales Forecasting with Conjoint Analysis by Addressing Its Key Assumptions with Sequential Game Theory and Macro-Flow Modeling. In A. Gustafsson, A. Herrman, \& F. Huber (Eds.), Berlin Heidelberg: Conjoint Measurement Methods and Application. Germany: Springer Press;

Wittink, D. R., \& Berestuen T. (2001). Forecasting with Conjoint Analysis. In J. S. Armstrong (Ed.), Principles of Forecasting: A Handbook for Researchers and Practitioners (pp. 147-68). New York: Springer Press. https://doi.org/10.1007/978-3-540-71404-0_18

Wu, W. Y., Linn, C. T., Fu, C. S., \& Sukoco, B. M. (2012). The Role of Endorsers, Framing, and Rewords on the Effectiveness of Dietary Supplement Advertising. Journal of Health Communication, 17, 54-75. http://dx.doi.org/10.1080/10810730.2011.585689

Yilmaz, C. E., Telci, E., Bodur, M., \& Iscioglu, T. E. (2011). Source Characteristics and Advertising Effectiveness: The Roles of Message Processing Motivation and Product Category Knowledge. International Journal of Advertising, 30(5), 889-914. https://doi.org/10.2501/IJA-30-5-889-914

Zhou, L. X., \& Whitla, P. (2013). How negative celebrity publicity influences consumer attitudes: The mediating role of moral reputation. Journal of Business Research, 66, 1013-1020. http://dx.doi.org/10.1016/j.jbusres.2011.12.025

Zufryden, F. S. (1989). How Much Should Be Spent for Advertising a Brand. Journal of Advertising Research, 29(2), 24-34.

\section{Copyrights}

Copyright for this article is retained by the author, with first publication rights granted to the journal.

This is an open-access article distributed under the terms and conditions of the Creative Commons Attribution license (http://creativecommons.org/licenses/by/4.0/). 